\title{
Study of personality accentuations based on a three-factor dichotomic typological approach
}

\author{
Konstantin Borisovich Malyshev ${ }^{1}$, Nikolay Gurgenovich Sobolev ${ }^{1}$, Aleksey Modestovich \\ Chirkov $^{1}$, Nina Nikolaevna Ershova ${ }^{2}$, and Tatyana Vyacheslavovna Maltseva ${ }^{31}$ \\ ${ }^{1}$ Vologda Institute of Law and Economics Federal Penitentiary Service of Russia, Faculty of \\ Psychology, Department of Legal Psychology and Pedagogy, Vologda, Russia \\ ${ }^{2}$ Vyatka State University, Pedagogical Institute, Department of Psychology, Kirov, Russia \\ ${ }^{3}$ Academy of Management of the Ministry of Internal Affairs of Russia, Department of Psychology, \\ Pedagogics and Personnel Management, Moscow, Russia
}

\begin{abstract}
A significant problem for practical psychologists is development of own methods necessary for particular and special cases of character research. This requires technologies for creating psychological diagnostic tools that might help to extend, streamline and show a complete picture of the personality, as well as a reliable system for validating the designed instrumentation. Practical psychology needs set forth a social mandate for the development of a classification technology highlighting psychological characteristics of individuals. Purpose of the research: creation of a new methodology for obtaining and measuring information concerning personality accentuations. Methods: a three-factor integrated dichotomic basic approach is used in modelling personality accentuations types and varieties of temperament. The respondents were represented by 187 students of Vologda State University. The research was carried out using the MMPI (Minnesota Multiphasic Personality Inventory) test and Holland's Professional Test Guide. The correlation analysis was used as well in data processing. The validation of the new methodology for measuring personality accentuations was made in terms of constructive validity. The research results extend the scientific concept defining the role and significance of the processes structuring the personality-specific psychological information, based on the use of a dichotomic three-factor basic approach which in turn will contribute to the development of theoretical psychologist's creative thinking. In addition, the results are aimed at obtaining complete and ordered measurement information on personality accentuations based on the application of the integrated-dichotomic three-factor basic typological approach that is of particular importance for the formation of practical psychologist's theoretical reasoning. The research results can be used for the purpose of extension of the psychodiagnostic training content.
\end{abstract}

Keywords: personality, psychometry, typology, temperament

\section{Introduction}

${ }^{1}$ Corresponding author: $\underline{\text { mtv-psy@mail.ru }}$ 
The study of personal characteristics and their subsequent typology was undertaken by both Russian and foreign researchers (B.G. Ananiev, A.G. Asmolov, L.I. Antsyferova, H. Eysenck, R. Bramson, E. Berne, E.A. Klimov, N.V. Kuzmina, R. Cattell, K. Leonhard, A. Harrison, E.G. Eidemiller, V.V. Yustickis, C.G. Jung and others). Following the theoretical analysis of the problem under consideration [1-4] and in view of its relevance, a contradiction was revealed between the existing methods of obtaining information on personality accentuations, that provided an incomplete and disordered picture in this aspect, and the need to develop a technology for creation of a personality accentuation measuring technique that would provide a due representation of a complete and ordered typological model of personality accentuations. It was the desire to find due ways to resolve this contradiction that outlined the problem of the present research.

The information about the typological psychological characteristics of a person served to be the object of the given research. The subject of the research, as determined by the authors, was a three-factor dichotomic typological approach as a mechanism for constructing a methodology that provides complete, orderly and measurable information about personality accentuations. The purpose of the research was to create a new methodology for obtaining and measuring the information about personality accentuations, as based on the use of a three-factor dichotomic typological approach. The hypothesis of the research was grounded on the assumption that the identification and measurement of personality accentuations are connected with a common-dichotomic three-factor typological basis of a person's professional orientation.

Proceeding from the goal and the formulated hypothesis, the following objectives were set: to create an algorithm for constructing a basic common-dichotomic three-factor typological construct with a view to obtain a relevant new baseline methodology and to validate this methodology.

The functional model of the mental structure adhered to by the authors in this study is presented in Table 1 in the form of a "three-factor model" that includes all of the major mental processes $[5,6]$.

Table 1. Perceptive psyche (consciousness) - substrate.

\begin{tabular}{|l|l|l|}
\hline Feeling (space) & Perception (energy) & Memory (time) \\
\hline "Reflection" axis & "Regulation" axis & "Realisation" axis \\
\hline AFFECT F(1) is a & WILL F(2) is an & REASONING ("SPIRIT") - \\
space factor & energy factor & F(3) is a time factor \\
\hline - attention, & - need, & - speech, \\
- emotion, & - motive, & - visualisation, \\
- feeling & - action & - imagination \\
\hline
\end{tabular}

\section{$2 \quad$ Methods}

The research was based on the three-factor integrated-dichotomic basic approach, the baseline factors analysis and the correlation analysis, Minnesota Multiphasic Personality Inventory (MMPI) test representing a common method for the study of normal and pathological personality, as well as Holland's Professional Test Guide [7, 8]. The deductive way of research was used (from the general to the particular), i.e. from the generalised to a particular basic typological structure of personality accentuations.

The validation of the new methodology for measuring personality accentuations was made in terms of constructive validity. This type of validity reflects the extent of representation of the explored psychological construct in the test results. The personality accentuation types serve as a psychological construct [7, 9-12]. 


\section{$3 \quad$ Results}

The construction of the new test matched the following logic. The MMPI scales "psychasthenia" - "hypochondria" have a common feature - the main peculiarities of these disorders in terms of "perception of information", that generates increased anxiety. The scales "hysteria" - "psychopathy" show similarity though the main characteristic feature of these disorders in the domain of "affect", which generates disturbed balance of the personality in the "space" of the society. The scales "hypomania" - "depression" are close in virtue of the main characteristic feature of these disorders in the area of "will", connected with "energy" disorders in the individual's behaviour and actions. The scales "paranoia" "schizophrenia" are united by the main characteristic feature of these disorders in the field of "thinking", which manifests itself within a certain period of "time" in the individual's reasoning. In case of "paranoia", thinking is mostly characterised by "synthesis" ("binding the non-connectable"), while "schizophrenia" is characterised by "analysis" ("discrete" logic of reasoning). The paper considers not in fact the mental diseases, but the "accentuations" that are "extreme expressions of normal personality types" and that show a common self-contained personal dichotomy "social - individual".

Table 2 presents the consistence of personality accentuations as per MMPI with temperamental traits of a personality on the basis of the three-factor integrated dichotomic typology of temperament. The authors relied on the reference semantic typology basis - the professional Holland's Typology of Personality [4].

Six basic types of personality accentuations as per MMPI (namely, "hysterical", "psychopathic", "hypomanic", "depressive", "paranoid", "schizoid") correlate with six types of individual's professional orientation ("conventional", "artistic", "social", "realistic", "enterprising", "intellectual") [2, 13].

The test developed for measuring the personality accentuation types as per MMPI includes 24 diagnostic judgements, of which 6 diagnostic judgements (from 1 to 6 ) match and measure the "substrate" types of accentuations as per MMPI ("psychasthenic" and "hypochondriacal"), while 18 diagnostic judgements (from 7 to 24) match and measure the basic personality accentuation types as per MMPI ("hysterical", "psychopathic", "hypomanic", “depressive", "paranoid", "schizoid") (see Table 3 ). Each judgement is assessed through the use of a symmetric six-point scale from $(-3)$ to $(+3)$. Following the measuring procedures, we obtain the extent of expression of personality accentuation types: (3-6) - low, (7-11) - medium, (12-18) - high, which can be considered as a typological baseline construct of personality accentuations.

Table 2. Correspondence of personality accentuations as per MMPI and individual's temperamental traits.

\begin{tabular}{|l|l|l|}
\hline $\begin{array}{l}\text { Basic types in a } \\
\text { three-factor } \\
\text { integrated dichotomic } \\
\text { model of } \\
\text { temperament }\end{array}$ & $\begin{array}{l}\text { Basic types of } \\
\text { personality } \\
\text { accentuations as per } \\
\text { MMPI }\end{array}$ & $\begin{array}{l}\text { Diagnostic judgements for measuring } \\
\text { personality accentuations as per MMPI }\end{array}$ \\
\hline $\begin{array}{l}\text { Melancholic } \\
\text { (perceptive) (social) }\end{array}$ & $\begin{array}{l}\text { Psychasthenia } \\
\text { Perceptive-social }\end{array}$ & $\begin{array}{l}\text { 1 I often show suspiciousness in different life } \\
\text { circumstances. } \\
\text { this "substrate" } \\
\text { personality type is am almost always worrying about } \\
\text { absent in J. Holland's } \\
\text { basic typology) }\end{array}$ \\
& $\begin{array}{l}\text { something. I am a doubting person and often show } \\
\text { indetermination and fearfulness. }\end{array}$ \\
\hline
\end{tabular}




\begin{tabular}{|c|c|c|}
\hline $\begin{array}{l}\text { Melancholic } \\
\text { (perceptive) } \\
\text { (individual) } \\
\text { Perceptive-individual } \\
\text { (this "substrate" } \\
\text { personality type is } \\
\text { absent in J. Holland's } \\
\text { basic typology) }\end{array}$ & $\begin{array}{l}\text { Hypochondria } \\
\text { (Hs). }\end{array}$ & $\begin{array}{l}\text { 4. I often have doubts and a feeling that I have } \\
\text { done something wrong. } \\
5 \text {. Most of the time I feel general weakness and } \\
\text { am prone to neurosis. } \\
6 \text {. I hate change of environment and easily lose } \\
\text { balance in social conflicts. }\end{array}$ \\
\hline $\begin{array}{l}\text { Choleric } \\
\text { (affective) (social) } \\
\text { Conventional }\end{array}$ & Hysteria (Hy). & $\begin{array}{l}\text { 7. I strive for people's paying attention to me. } \\
\text { 8. I have periods of anxiety that do not let me } \\
\text { stay still. } \\
\text { 9. It is important for me that people around } \\
\text { admire me. }\end{array}$ \\
\hline $\begin{array}{l}\text { Choleric } \\
\text { (affective) } \\
\text { (individual) } \\
\text { Artistic }\end{array}$ & Psychopathy (Pd). & $\begin{array}{l}\text { 10. I have an impression that no one } \\
\text { understands me. } \\
\text { 11. My mood often changes and I can be } \\
\text { touchy, excitable and hypersensitive to } \\
\text { situations. } \\
\text { 12. I am often aggressive, confrontational and } \\
\text { disregard social norms and values. }\end{array}$ \\
\hline $\begin{array}{l}\text { Phlegmatic } \\
\text { (strong-minded) } \\
\text { (social) } \\
\text { Social }\end{array}$ & Hypomania (Ma). & $\begin{array}{l}\text { 13. I am normally in high spirits regardless of } \\
\text { circumstances. I work intensively. } \\
\text { 14. I feel no difficulty keeping up a } \\
\text { conversation with a person I have just met. } \\
\text { 15. I am an active, high-powered, enterprising } \\
\text { and cheerful person. }\end{array}$ \\
\hline $\begin{array}{l}\text { Phlegmatic person } \\
\text { (strong-minded) } \\
\text { (individual) } \\
\text { Realistic }\end{array}$ & Depression (D). & $\begin{array}{l}\text { 16. I am a sensitive, anxious person and often } \\
\text { show shyness and faintheartedness. } \\
\text { 17. I am a diligent, conscientious and obliging } \\
\text { person, but I do not always make decisions on } \\
\text { my own. } \\
\text { 18. I often feel difficulty getting involved in } \\
\text { work, I show hesitancy, fall into despair in case } \\
\text { of failures. }\end{array}$ \\
\hline $\begin{array}{l}\text { Sanguine } \\
\text { (reasoning) (social) } \\
\text { Enterprising }\end{array}$ & Paranoia (Pa). & $\begin{array}{l}\text { 19. I have a tendency to form overvalued ideas. } \\
20 \text {. I am a suspicious person, and it seems to } \\
\text { me that something is being plotted against me; } \\
\text { I am inclined to "synthesis" in reasoning and } \\
\text { try to "bind the non-connectable". } \\
21 \text {. I am often aggressive, vindictive and } \\
\text { conflict-prone to people around. }\end{array}$ \\
\hline $\begin{array}{l}\text { Sanguine } \\
\text { (reasoning) } \\
\text { (individual) } \\
\text { Intellectual }\end{array}$ & Schizoid (Se). & $\begin{array}{l}\text { 22. I am capable of "analysis", I perceive well } \\
\text { abstract images and feel their subtlety. } \\
\text { 23. Everyday joys and sorrows do not evoke } \\
\text { emotional response in me. } \\
\text { 24. I usually feel lonely in interpersonal } \\
\text { relationships and in the society. }\end{array}$ \\
\hline
\end{tabular}


Many diagnostic techniques, both domestic and borrowed from foreign experience, are used without a preliminary theoretical analysis of completeness and structure of psychological characteristics included in the typological structure of the concept under study $[14,15]$. One of the reasons for this is the imperfection of the psychological typologies as such, their inconsistency with concrete methods.

The results of testing involving Vologda State University students (187 persons) obtained using the new method for defining the personality accentuation types correlate with the diagnostic results obtained according to J. Holland's method for determining the individual's professional orientation, as follows [2]: "hysterical (1)" - "conventional (7)", "psychopathic (2)" - "artistic (8)", "hypomanic (3)" - "social (9)", "depressive (4)" "realistic (10)", "paranoid (5)" - "adventurous (11)", "schizoid (6)" - "intelligent (12)".

The spread of correlation coefficients from 0.49 to 0.73 between the test types that reveal the personality accentuation types and the valid test similar in typological construct, measuring professional types of personality, confirms that the newly-developed test "measures" the same personality traits as the three-factor basic professional reference test (see table 3). The reference valid baseline test represents an independent criterion and makes it possible to verify the criterion validity of the newly compiled test.

Table 3. Correlations between personality accentuation types and professional personality types.

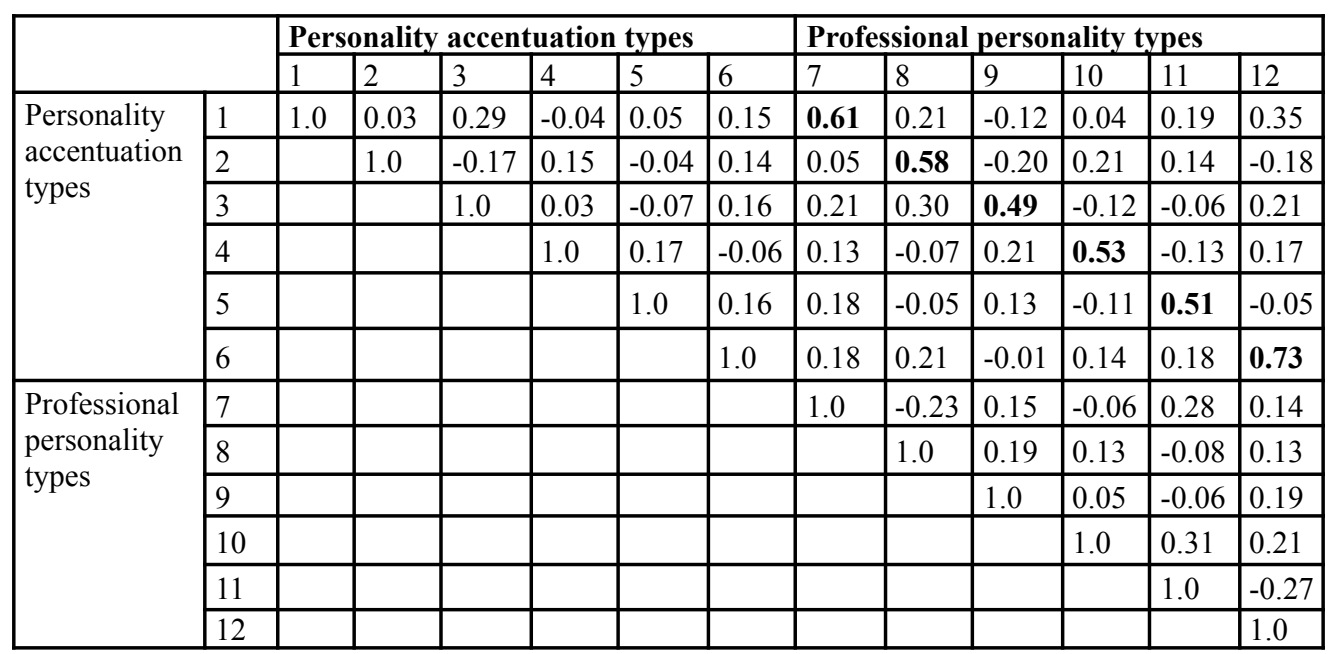

\section{Conclusion}

The research results expand the scientific concept of the role and significance of the processes structuring the psychological information about the personality, as based on the use of the dichotomic three-factor basic approach. The study validated the possibility of obtaining complete, orderly and measurable information about personality accentuations, as based on the common-dichotomic three-factor basic typological approach. Following the elaboration work, two new professional psychological types were identified ("perceptive-social" and "perceptive-individual").

\section{References}

1. A.N. Andreev, P.I. Artemyeva, App. Psy. Pedag. 3, 28-38 (2020).

https://doi.org/10.1'2737/2500-0543-2020-2838 
2. K.B. Malyshev, O.A. Malysheva, Yaroslavl Pedag. Bul. 5(109), 112-118 (2019)

3. E.N. Sepiashvili, Edu. Sci. Acad. Brainpower 1, 228-233 (2014)

4. G. Matthews et al., Person. Indiv. Dif. 169, 109969 (2021)

5. K.B. Malyshev, O.A. Malysheva, Metodologiya bazisnogo podkhoda v sovremennykh psikhologicheskikh issledovaniyakh [Methodology of Baseline Approach in Modern Psychological Research] (Vologda-Kursk, 2020)

6. D.N. Zavalishina, V.A. Barabanshchikova (eds.), Printsip sistemnosti v psikhologicheskikh issledovaniyakh [Principle of Consistency in Psychological Research] (Nauka, Moscow, 2016)

7. B.V. Kulagin, Osnovy professionalnoi psikhodiagnostiki [Fundamentals of professional psychodiagnostics] (Medicine, St. Petersburg, 2017)

8. N.N. Gorach, et al., Int. J. Rec. Tech. Eng. 8(4), 12667-12668 (2019). https://doi.org/10.35940/ijrte.D9071.118419

9. J.K. Flake, J. Pek, E. Hehman, Soc. Psy. Pers. Sci. 8(4), 370-378 (2017)

10. M. Guillot-Valdés, A. Guillén-Riquelme, G. Buela-Casal, Int. J. Clin. Health Psy. 19(3), 243-250 (2019)

11. Robert F. Bornstein, J. Pers. Assess. 97(5), 446-455 (2015). https://doi.org/10.1080/00223891.2015.1027346

12. K.Y. Telesheva, et al., App. Psy. Pedag. 2, 51-66 (2020). https://doi.org/10.12737/2500-0543-2020-51-66

13. A.V. Belorusova, Sci. Meth. Elect. J. Conc. 18, 16-20 (2015)

14. V.V. Kozlov, V.A. Mazilov, V.F. Petrenko, Meth. Mod. Psy. 7, 3-6 (2017)

15. V.A. Mazilov, Metodologiya psikhologicheskoi nauki: istoriya i sovremennost [Methodology of Psychological Science: History and Contemporaneity] (Yaroslavl State Pedagogical University, Yaroslavl, 2017) 